\title{
Effect of exogenous salicylic acid or indole acetic acid on their endogenous levels, germination, and growth in maize
}

\author{
Ragab A. El-Mergawi (D) and Mohamed S. A. Abd El-Wahed
}

\begin{abstract}
Background: Exogenous hormone applications modify the plant growth and development by inducing changes in their endogenous contents. However, it is not clear whether the effects of exogenous hormones on growth are direct or related with changes induced in endogenous hormones. Laboratory and greenhouse experiments were conducted to study the effect of exogenous salicylic acid (SA) or indole acetic acid (IAA) on endogenous levels in soaked seeds, 5-day-old seedlings, and in vegetative growth of foliar-sprayed plants. The effects of different concentrations of two hormones on germination and growth of maize were also studied.

Results: The effect of presoaking maize seeds in solutions of SA or IAA $(0,0.25,0.5,1$, and $2 \mathrm{mM})$ on their endogenous contents in soaked seeds or in 5-day-old seedlings. Soaked seeds absorbed more SA than IAA. In young seedlings, the majority of two hormones which absorbed during seed soaking remained in the residual seeds. Presoaking seeds in SA or IAA solutions suppressed the growth of 5-day-old seedlings. In the greenhouse experiment, endogenous SA and IAA increased after spraying two compounds at $0.25-2 \mathrm{mM}$, peaking 2 days after treatment then decreased on. However, plants treated with SA at $1 \mathrm{mM}$ or $2 \mathrm{mM}$ continued to pose higher levels of endogenous SA, 8 days later. At 20 days after treatments, all tested concentrations of two hormones significantly increased the fresh and dry weights of the whole plant. These inducing effects disappeared 40 days after spraying.

Conclusion: The obtained results demonstrated the changes in endogenous SA and IAA in soaked seeds, seedling, and foliar-sprayed plants due to their exogenous application. However, concentrations of two hormones did not produce any permanent enhancement effects on germination and plant growth.
\end{abstract}

Keywords: Zea mays, Salicylic acid, Indole acetic acid, Uptake of hormones, Germination, Plant growth

\section{Background}

Salicylic acid (SA) and indole acetic acid (IAA) are plant hormones involved in the regulation of many physiological processes in plants. Interestingly, these two hormones share a common precursor-chorismate, the final product of the shikimate pathway. Chorismate is responsible for aromatic amino acids including tryptophan, and through several steps, it can generate the IAA. Meanwhile,

\footnotetext{
* Correspondence: ragabelmergawi05@hotmail.com

Botany Department, Agricultural and Biological Research Division, National Research Centre, Dokki, Giza, Cairo 12622, Egypt
}

chorismate can be converted into isochorismate which transformed into SA (Pérez-Llorca et al. 2019).

SA is a phenolic compound, which contributes to the regulation of many growth and development processes, such as seed germination, photosynthesis, respiration, flowering, and senescence (Vicente and Plasencia 2011). Moreover, SA also acts as a signaling molecule in the activation of the plant defense responses against many stress factors (Wani et al. 2017), whereas IAA is one of the most important phytohormones, and it plays essential roles in different processes, including gametogenesis, embryogenesis, seedling growth, vascular patterning, and

\section{Springer Open}

(ㅇ The Author(s). 2020 Open Access This article is licensed under a Creative Commons Attribution 4.0 International License, which permits use, sharing, adaptation, distribution and reproduction in any medium or format, as long as you give appropriate credit to the original author(s) and the source, provide a link to the Creative Commons licence, and indicate if changes were made. The images or other third party material in this article are included in the article's Creative Commons licence, unless indicated otherwise in a credit line to the material. If material is not included in the article's Creative Commons licence and your intended use is not permitted by statutory regulation or exceeds the permitted use, you will need to obtain permission directly from the copyright holder. To view a copy of this licence, visit http://creativecommons.org/licenses/by/4.0/. 
flower development (Zhao 2010). Endogenous hormones are tightly controlled through various mechanisms, such as biosynthesis, degradation, transportation, and conjugate formation (Korasick et al. 2013). However, it is not clear whether the effects of exogenous hormones on plant growth are direct or whether they are connected with their effects on endogenous hormones (Szalai et al. 2011). In most tissues, the endogenous IAA responded in a distinct manner to varying amounts of exogenous IAA application (Zhou et al. 2017). Moravcová et al. (2018) studied the effect of pre-treatment of maize seeds with SA in different concentrations on the level of endogenous SA. They found that soaking seeds in SA at 50 $\mu \mathrm{M}$ resulted in a significant increase in endogenous SA, but application $500 \mu \mathrm{M}$ produced a significant decrease in the level of endogenous SA in the newly formed roots, whereas soaking pea seeds in SA caused increases in both free and pound SA contents in the seeds (Szalai et al. 2011). Higher levels of endogenous IAA might cause an inhibitory effect, so the optimum endogenous level must be controlled. Cai et al. (2018) found that at 3 days after exogenous application of SA, the endogenous SA reached the maximum and subsequently decreased until it reached the level of control plants at 7 days later.

In the present study, we investigated the effect of presoaking maize seeds in SA or IAA on germination, uptake, and distribution of endogenous hormones in young seedlings. Moreover, growth effects and the changes in the endogenous SA and IAA over time as a response to spraying of two hormones in leaves of greenhousegrown maize were also studied.

\section{Methods}

\section{Source of plants}

Seeds of maize (Zea mays cv. Giza 2) were obtained from Agricultural Research Center, Egypt.

\section{Germination experiment}

Maize seeds of the same size were sterilized with $10 \%$ $(\mathrm{v} / \mathrm{v})$ sodium hypochlorite solution for $5 \mathrm{~min}$ and washed with distilled water. Seeds were soaked for 48 $\mathrm{h}$ in the dark at $25{ }^{\circ} \mathrm{C}$ in distilled water (control) or in either SA or IAA solutions four different concentrations for each $(0.25,0.5,1$, and $2 \mathrm{mM})$. The soaked seeds were germinated in Petri dishes. Ten seeds of each treatment were placed in a 9-cm plastic Petri dish lined with a single Whatman No. 1 filter paper, then $10 \mathrm{~mL}$ of distilled water was added onto filter paper. Four replicates of each treatment were placed, in a completely randomized manner, in a growth chamber at $25{ }^{\circ} \mathrm{C}$. After 5 days, germination percentage, shoot length, and root length of germinated seeds were determined. Moreover, endogenous SA and IAA were determined in soaked seeds before incubation as well as in various tissues of young seedlings.

\section{Greenhouse experiment}

An experiment was conducted to study the effect of foliar spray of SA or IAA on growth and the changes in endogenous SA and IAA over time of greenhouse-grown maize. The seeds were sown on May 1, 2018, in pots (30-cm diameter) filled with $4 \mathrm{~kg}$ soil (sand: peat moss, $3: 1$, w/w) at 5 maize seeds per pot. Ten days after complete germination, three seedlings were preserved in each pot. Then, pots were divided into nine groups with four replicates; each group was sprayed with one of the following treatments: distilled water (control) or SA solution $(0.25,0.5,1$, and $2 \mathrm{mM})$ or IAA solution $(0.25$, $0.5,1$, and $2 \mathrm{mM})$. The solution was sprayed using an Epoca sprayer (Italy) evenly over the entire surface of the plant, including the adaxial and abaxial surface of leaves. The pots were placed in a greenhouse $\left(25 \pm 3{ }^{\circ} \mathrm{C}\right.$, $12 \mathrm{~h}$ photoperiod), arranged in a completely randomized design and irrigated with equal amounts of half-strength Hoagland solution. At 2, 4, and 8 days after treating (DAT), vegetative plant samples were taken to determine the endogenous concentration of SA and IAA. Moreover, at 20 and $40 \mathrm{DAT}$, plant growth parameters were evaluated in terms of plant height $(\mathrm{cm})$, leaves' number, fresh and dry weights of leaves (g), and fresh and dry weights of a plant (g).

\section{Extraction and determination of SA and IAA}

Vegetative plant samples were collected, fast cleaned with distilled water to remove the SA or IAA residues, oven-dried at $50{ }^{\circ} \mathrm{C}$, and ground in a mortar. The extraction of endogenous SA and IAA was performed according to Matallo et al. (2009). One hundred milligrams of plant powder was placed in a centrifuge tube, and $10 \mathrm{~mL}$ of acidified water ( $\mathrm{pH} 2.5)$ was added and subjected to an ultra-sonication bath with an ultrasonic frequency of $50 / 60 \mathrm{~Hz}$ for $30 \mathrm{~min}$. Samples were subjected to centrifugation at $4000 \mathrm{~g}$ for $10 \mathrm{~min}$ at $20{ }^{\circ} \mathrm{C}$. The supernatant was collected and filtered through a nylon filter $45 \mu \mathrm{m}$. Quantification of SA and IAA was performed by highperformance liquid chromatography (HPLC), LC-10 AD, Shimadzu, Japan. The two phytohormones were analyzed using a Luna RP-C18 (2) column $(250 \times 4.6 \mathrm{~mm}$ i.d, $5 \mu \mathrm{m}$, Phenomenx). The mobile phase of phosphate buffer ( $\mathrm{pH} 6.5)$ in methanol $(90: 10, \mathrm{v} / \mathrm{v})$ was used at a flow rate $0.9 \mathrm{~mL} / \mathrm{min}$. The detecting wavelength was $220 \mathrm{~nm}$. Standard of SA and IAA were purchased from Sigma Aldrich. For each compound, the calibration curve was constructed with the concentrations of the standards $(0.01-0.1 \mathrm{mg} / \mathrm{mL})$ that covered the range of levels of the compounds found in the plant tissues. The 
retention time in min was 9.42 for SA and 10.29 for IAA.

\section{Statistical analysis}

Analyses were performed in triplicate. The data were subjected to analysis of variance according Gomez and Gomez (1984), and comparison of means (LSD, 5\% level) was performed using Stat graphics Plus Version 5.1.

\section{Results}

\section{Germination experiment}

As shown in Table 1, soaking maize seeds in SA solutions at $0.25-2 \mathrm{mM}$ for $48 \mathrm{~h}$ caused gradual increases the endogenous SA in treated seeds when compared with water-soaked seeds. Concentration and amount of SA in SA-soaked seeds ranged between 19.1 and $152.2 \mu \mathrm{g} / \mathrm{g}$ and between 6.8 and $55.2 \mu \mathrm{g} /$ seed compared with $0.7 \mathrm{of} \mu \mathrm{g} / \mathrm{g}$ and $0.3 \mu \mathrm{g} / \mathrm{seed}$ for control seeds, respectively. It was found that the endogenous SA content was higher than those found in the corresponding control (Table 1). Pre-treating seeds with the highest concentration of SA $(2 \mathrm{mM})$ resulted in a great accumulation of this compound and a complete inhibition in the germination of maize seeds. No great differences in the concentration of endogenous SA between developed roots and developed shoots of SA-pretreated seedlings. These two parts possessed between 8-times to 10-times of endogenous SA, relative to control. Meanwhile, in all tested seedlings, the residual seeds tended to accumulate more amount of SA than those accumulated in shoots or roots.

Soaking maize seeds in IAA solutions for $48 \mathrm{~h}$ caused a gradual increase in the concentration and amount of endogenous IAA, as the concentration increased (Table 2). Concentration and amount of endogenous IAA in $2 \mathrm{mM}$ IAA-treated seeds constituted $27.2 \mu \mathrm{g} / \mathrm{g}$ and $9.55 \mu \mathrm{g} / \mathrm{seed}$ corresponded with $1.3 \mu \mathrm{g} / \mathrm{g}$ and $0.5 \mu \mathrm{g} / \mathrm{seed}$ for control, respectively. The application of IAA led to increase the concentration and amount of endogenous IAA in all seedling tissues. The shoot, root, and residual seeds of IAA pre-soaked seedlings possessed between 1.36-1.66, $1.78-3.22$, and $2.9-7.73 \mu \mathrm{g} / \mathrm{g}$, compared with $1.27,1.56$, and $0.97 \mu \mathrm{g} / \mathrm{g}$ for those of control, respectively. The IAA concentration was higher in residual seeds than in the developed roots or shoots of pretreated seedlings. Moreover, the residual seeds tended to accumulate more IAA ( $0.42-$ $3.42 \mu \mathrm{g} / \mathrm{seed})$ than those accumulated in the shoots $(0.1-$ $0.16 \mu \mathrm{g} / \mathrm{seed})$ or roots $(0.19-0.36 \mu \mathrm{g} / \mathrm{seed})$ of all tested seedlings.

Pre-soaking seeds in SA or in IAA solutions led to different effects on germination and seedling growth (Table $3)$. Soaking seeds in higher SA concentration $(2 \mathrm{mM})$ completely inhibited the germination of maize seeds. Also, a significant decrease in the germination percentage was found due to the application of SA at $1 \mathrm{mM}$ or $0.5 \mathrm{mM}$ as well as IAA at $0.5 \mathrm{mM}$ or $0.25 \mathrm{mM}$ as compared with control (water germinated seeds). On the contrary, the application of low SA dose $(0.25 \mathrm{mM})$ and high IAA dose (2 $\mathrm{mM})$ in the seed pre-treatment caused significant increases in germination percentage when compared with control. Moreover, all SA and IAA pre-treatments caused decreases in shoot length as compared with control. A gradual decrease in shoot length was obtained by increasing the dose of SA pretreatments decreasing the dose of IAA pre-treatments. Hence, the most reduction effect was recorded for the highest SA dose and for the lowest IAA dose. As shown in Table 3, the root length of 5-day-old seedlings exhibited the most reduction effects as affected by presoaking seeds in all SA doses and IAA doses.

\section{Greenhouse experiment}

Changes in endogenous SA and IAA over time of greenhouse-grown maize as affected by foliar spray of these two compounds were illustrated in Fig. 1. The results indicated that application SA at $0.25 \mathrm{mM}$ did not produce any remarkable effect on endogenous SA when compared with control, whereas spraying SA at 0.5-2 $\mathrm{mM}$ caused a concentration-dependent increase in SA

Table 1 Effect of pre-soaking maize seeds in SA for 48 hours on concentration and distribution of endogenous SA in soaked seeds and 5-days-old seedlings

\begin{tabular}{|c|c|c|c|c|c|c|c|c|}
\hline \multirow{3}{*}{$\begin{array}{l}\text { Endogenous } \\
\text { SA }\end{array}$} & \multicolumn{2}{|c|}{ Soaked seeds } & \multicolumn{6}{|c|}{ 5-days-old seedlings } \\
\hline & \multirow{2}{*}{$\begin{array}{l}\text { Conc } \\
\mu g / g\end{array}$} & \multirow{2}{*}{$\begin{array}{l}\text { Amount } \\
\mu \mathrm{g} / \mathrm{seed}\end{array}$} & \multicolumn{2}{|l|}{ Shoot } & \multicolumn{2}{|l|}{ Root } & \multicolumn{2}{|l|}{ Seeds } \\
\hline & & & Conc $\mu \mathrm{g} / \mathrm{g}$ & Amount $\mu \mathrm{g} /$ seed & Conc $\mu \mathrm{g} / \mathrm{g}$ & Amount $\mu \mathrm{g} /$ seed & Conc $\mu \mathrm{g} / \mathrm{g}$ & Amount $\mu \mathrm{g} / \mathrm{seed}$ \\
\hline $2 \mathrm{mM} \mathrm{SA}$ & $152.2^{a}$ & $55.2^{a}$ & - & - & - & - & $129.4^{a}$ & $51.7^{a}$ \\
\hline $1 \mathrm{mM} \mathrm{SA}$ & $53.5^{b}$ & $19.0^{b}$ & $19.8^{\mathrm{a}}$ & $1.76^{\mathrm{b}}$ & $20.4^{\mathrm{a}}$ & $1.69^{b}$ & $15.1^{b}$ & $6.5^{b}$ \\
\hline $0.5 \mathrm{mM} \mathrm{SA}$ & $42.4^{c}$ & $16.7^{\mathrm{b}}$ & $17.4^{\mathrm{a}}$ & $2.20^{a}$ & $17.6^{\mathrm{a}}$ & $2.11^{\mathrm{a}}$ & $5.4^{b}$ & $2.6^{b}$ \\
\hline $0.25 \mathrm{mM} \mathrm{SA}$ & $19.1^{d}$ & $6.8^{c}$ & $15.9^{\mathrm{a}}$ & $1.48^{c}$ & $16.5^{\mathrm{a}}$ & $1.15^{\mathrm{c}}$ & $5.6^{b}$ & $2.4^{b}$ \\
\hline Control & $0.7^{\mathrm{e}}$ & $0.3^{d}$ & $2.0^{b}$ & $0.25^{\mathrm{d}}$ & $1.9^{b}$ & $0.24^{d}$ & $1.6^{b}$ & $0.7^{b}$ \\
\hline
\end{tabular}


Table 2 Effect of pre-soaking maize seeds in IAA for 48 hours on concentration and distribution of endogenous IAA in soaked seeds and 5-days-old seedlings

\begin{tabular}{|c|c|c|c|c|c|c|c|c|}
\hline \multirow{3}{*}{$\begin{array}{l}\text { Endogenous } \\
\text { IAA }\end{array}$} & \multicolumn{2}{|c|}{ Soaked seeds } & \multicolumn{6}{|c|}{ 5-days-old seedlings } \\
\hline & \multirow{2}{*}{$\begin{array}{l}\text { Conc } \\
\mu \mathrm{g} / \mathrm{g}\end{array}$} & \multirow{2}{*}{$\begin{array}{l}\text { Amount } \\
\mu \mathrm{g} / \mathrm{seed}\end{array}$} & \multicolumn{2}{|l|}{ Shoot } & \multicolumn{2}{|l|}{ Root } & \multicolumn{2}{|l|}{ Seeds } \\
\hline & & & Conc $\mu \mathrm{g} / \mathrm{g}$ & Amount $\mu \mathrm{g} / \mathrm{seed}$ & Conc $\mu \mathrm{g} / \mathrm{g}$ & Amount $\mu \mathrm{g} / \mathrm{seed}$ & Conc $\mu \mathrm{g} / \mathrm{g}$ & Amount $\mu \mathrm{g} / \mathrm{seed}$ \\
\hline $2 \mathrm{mM} I \mathrm{AA}$ & $27.2^{\mathrm{a}}$ & $9.55^{a}$ & $1.66 a$ & $0.16^{\mathrm{a}}$ & $3.22^{\mathrm{a}}$ & $0.36^{b}$ & $7.73^{\mathrm{a}}$ & $3.42^{\mathrm{a}}$ \\
\hline $1 \mathrm{mM} \mid \mathrm{AA}$ & $23.1^{b}$ & $9.12^{a}$ & $1.43 a b$ & $0.13^{b}$ & $3.24^{\mathrm{a}}$ & $0.47^{\mathrm{a}}$ & $3.54^{\mathrm{b}}$ & $1.32^{\mathrm{b}}$ \\
\hline $0.5 \mathrm{mM}$ IAA & $20.9^{b}$ & $7.57^{b}$ & $1.38 a b$ & $0.12^{\mathrm{b}}$ & $2.48^{\mathrm{b}}$ & $0.23^{c}$ & $2.51^{\mathrm{b}}$ & $1.20^{\mathrm{b}}$ \\
\hline $0.25 \mathrm{mM}$ IAA & $21.3^{b}$ & $7.24^{b}$ & $1.36 a b$ & $0.10^{\mathrm{b}}$ & $1.78^{c}$ & $0.15^{c}$ & $2.90^{\mathrm{b}}$ & $1.33^{b}$ \\
\hline Control & $1.3^{c}$ & $0.50^{c}$ & $1.27 \mathrm{~b}$ & $0.10^{\mathrm{b}}$ & $1.56^{\mathrm{c}}$ & $0.19^{c}$ & $0.97^{c}$ & $0.42^{c}$ \\
\hline
\end{tabular}

Mean value is average of four replicates. In the same column with different letter(s) are significantly different (P $\leq 0.05)$. Conc concentration

content that reached a peak of 2 DAT and then gradually decreased by the times. Moreover, application high SA doses $(1$ or $2 \mathrm{mM})$ produced a continuous increase in endogenous SA over the entire time of the measuring period. Data in Fig. 2 demonstrated that the concentration of endogenous IAA was responded positively to all IAA exogenous application treatments when determined at 2 DAT or 4 DAT. Such an increase depended on the concentration, and it ranged between $10 \%$ and $34 \%$ at 2 DAT and between $3 \%$ and $24 \%$, at 4 DAT. However, at 8 DAT, the pronounced increase in the level of endogenous IAA was obtained only by application IAA at $2 \mathrm{mM}$.

The effects of foliar spray of SA on vegetative growth of greenhouse-grown plants are presented in Table 4. At 20 DAT, no significant effects of SA application were observed on plant height and number of leaves as compared with control plants. Also, the lower concentration of SA $(0.25 \mathrm{mM})$ did not cause any changes in most vegetative growth parameters. However, the application of SA at the higher concentrations $(0.5-2 \mathrm{mM})$ produced significant increases in the fresh weight of plants and leaves and dry weight of plants and leaves, as compared with control. Maximum increases in these growth parameters were obtained by treating plants with $\mathrm{SA}$ at 2

Table 3 Impact of SA and IAA pre-soaking seeds on germination and seedling traits (\% of control)

\begin{tabular}{llll}
\hline Treatments & Germination \% & Shoot length & Root length \\
\hline $2 \mathrm{mM} \mathrm{SA}$ & $0.0 \pm 0.0^{\mathrm{d}}$ & $0.0 \pm 0.0^{\mathrm{d}}$ & $0.0 \pm 0.0^{\mathrm{g}}$ \\
$1 \mathrm{mM} \mathrm{SA}$ & $75.0 \pm 2.3^{\mathrm{c}}$ & $61.5 \pm 2.1^{\mathrm{c}}$ & $44.3 \pm 2.1^{\mathrm{e}}$ \\
$0.5 \mathrm{mM} \mathrm{SA}$ & $71.7 \pm 3.2^{\mathrm{c}}$ & $81.9 \pm 3.3^{\mathrm{b}}$ & $54.9 \pm 2.6^{\mathrm{cd}}$ \\
$0.25 \mathrm{mM} \mathrm{SA}$ & $106.7 \pm 4.5^{\mathrm{a}}$ & $82.1 \pm 4.1^{\mathrm{b}}$ & $46.0 \pm 1.9^{\mathrm{e}}$ \\
$2 \mathrm{mM} \mathrm{IAA}$ & $108.3 \pm 3.9^{\mathrm{a}}$ & $92.8 \pm 2.8^{\mathrm{a}}$ & $74.7 \pm 3.2^{\mathrm{b}}$ \\
$1 \mathrm{mM} \mathrm{IAA}$ & $103.3 \pm 4.8^{\mathrm{ab}}$ & $78.9 \pm 2.1^{\mathrm{b}}$ & $58.3 \pm 3.0^{\mathrm{c}}$ \\
$0.5 \mathrm{mM}$ IAA & $93.3 \pm 2.7^{\mathrm{b}}$ & $77.2 \pm 2.2^{\mathrm{b}}$ & $49.7 \pm 1.7^{\mathrm{de}}$ \\
$0.25 \mathrm{mM}$ IAA & $78.3 \pm 3.1^{\mathrm{c}}$ & $67.6 \pm 2.0^{\mathrm{c}}$ & $35.8 \pm 1.9^{\mathrm{f}}$ \\
Control & $100.0 \pm 3.6^{\mathrm{ab}}$ & $100.0 \pm 3.8^{\mathrm{a}}$ & $100.0 \pm 3.3^{\mathrm{a}}$ \\
\hline
\end{tabular}

Data within a column followed with the same letter are not significantly different at the level $5 \%$
$\mathrm{mM}$, whereas, at $40 \mathrm{DAT}$, the enhancing effect of all SA treatments on growth parameters disappeared.

As shown in Table 5, foliar spray of IAA at all tested doses tended to enhance the vegetative growth parameters of maize when measured 20 DAT, but the effect on plant height and number of leaves did not reach the level of significance. Meanwhile, the most effective treatment was obtained by SA at $0.5 \mathrm{mM}$. This treatment achieved more than $50 \%$ increases in fresh and dry weights of leaves and plants, relative to control. At 40 DAT, the significant increase in growth parameters was observed only when application IAA at the highest dose $(2 \mathrm{mM})$. This treatment produced more than $15 \%$ increases in different growth traits, as compared with those of control.

\section{Discussion}

Exogenous hormone applications modify the plant growth and development by inducing changes in their endogenous contents. However, it is not clear whether the effects of exogenous hormones on growth are direct or whether they are related with changes induced in endogenous hormones (Szalai et al. 2011). We determined the changes in the endogenous SA and IAA after soaking seeds in different concentrations of these two compounds for $48 \mathrm{~h}$ and their distribution in seedlings after complete germination of pre-soaked seeds in distilled water for another 5 days. The results indicated that the exogenous applications of SA and IAA were correlated with the changes in their endogenous contents in soaked seeds and 5-day-old seedlings. These results are in line with those obtained by Kim et al. (2006) and Moravcová et al. (2018). Meanwhile, a higher ability of maize seeds for uptake SA was detected when compared with the relatively low ability of seeds on uptake IAA. The low ability of soaked seeds for uptake IAA was previously reported by Kim et al. (2006). Seeds soaked in the highest concentration of SA (2 mM) accumulated a great amount of SA which could be responsible for preventing the germination of seeds. In this respect, a dramatic 


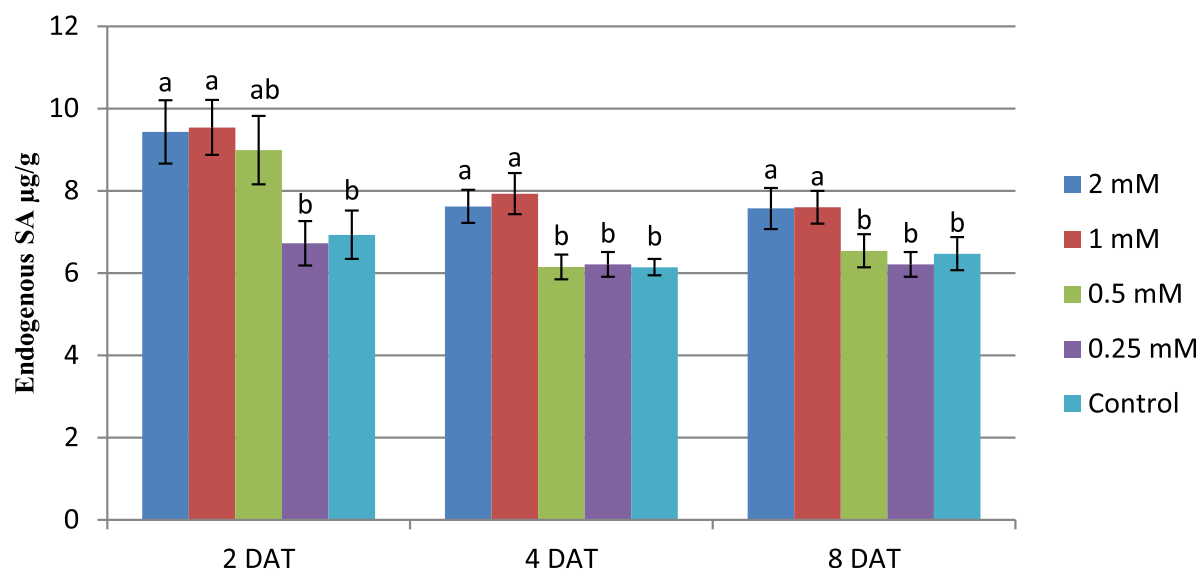

Fig. 1 Changes in endogenous SA over time in maize plants in response to their exogenous application at different levels

inhibition of the germination process was reported when soaking maize seeds in SA above a concentration of 1 mM (Guan and Scandalios 1995), whereas Marambe and Ando (1992) found that increasing the phenolic acid concentrations in germination media reduced water uptake, a-amylase activity, and germination rate of sorghum seeds.

In the present study, we determined the effect of presoaking seeds in SA and IAA on the distribution of endogenous SA and IAA in different tissues of 5-day-old seedlings. The two hormones were found in different seedling tissues, and their contents were positively correlated with the applied concentrations. The major amounts of SA or IAA in the residual seeds of young seedlings, but developed shoots and roots accumulated low amounts of two compounds. In line with these results, Szalai et al. (2011) found that the majority of the SA absorbed during seed soaking remained in the seeds.

In this study, pre-soaking seeds in SA or in IAA solutions for $48 \mathrm{~h}$ achieved different effects on germination and seedling growth of 5-day-old maize plants. In the literature, there are divergent data about the effect of different concentrations of SA and IAA on seed germination and seedling development (Rajjou et al. 2006; Chauhan et al. 2009; Xiao et al. 2014). In this study, except for the enhancing effect of lower SA concentration $(0.25 \mathrm{mM})$ and higher IAA one $(2 \mathrm{mM})$ on germination percentage, all SA and IAA treatments negatively reduced the germination percentage of maize seeds. An inhibitory effect of SA on germination percentages of many plant species, especially at high applied concentrations was previously recorded by many investigators (Negi and Prasad 2001; Chandra et al. 2007; ElMergawi 2019). The inhibitory effect of application high SA concentrations on germination can be attributed to toxic stress (Canakci and Munzuroglu 2007). In this concern, Muscolo et al. (2001) found that the phenolic acids inhibited the germination of pinus laricio by inhibiting the activities of glycolysis and the oxidative pentose phosphate pathway enzymes. However, an

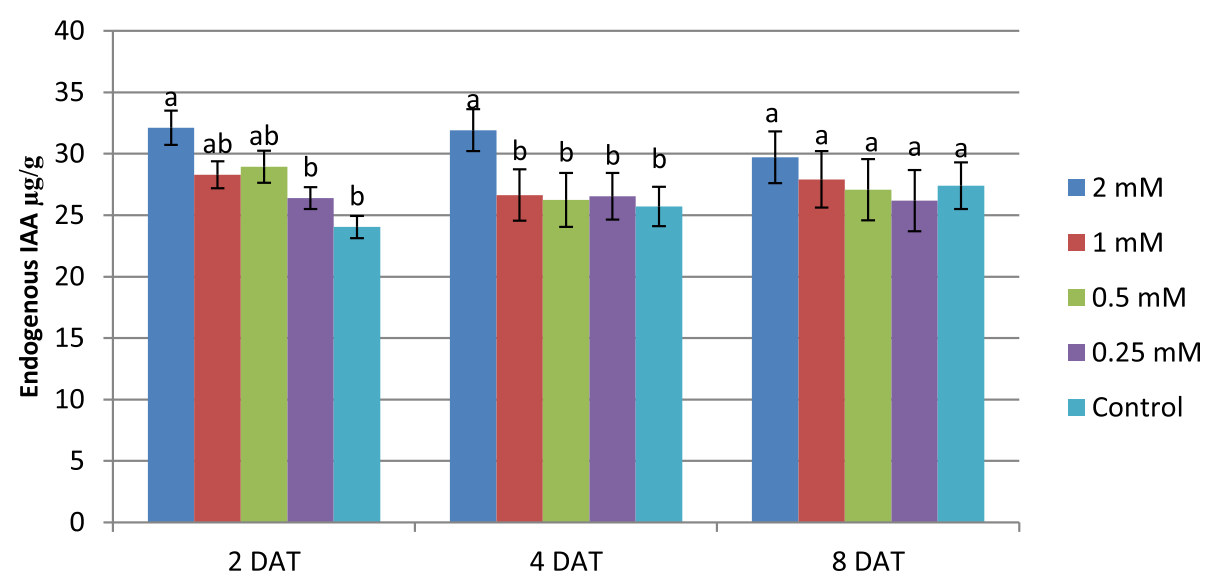

Fig. 2 Changes in endogenous IAA over time in maize plants in response to their exogenous application at different levels 
Table 4 Effect of SA foliar spray on vegetative growth of maize plants

\begin{tabular}{|c|c|c|c|c|c|c|}
\hline $\begin{array}{l}\text { Criteria } \\
\text { Treatment }\end{array}$ & Plant height $(\mathrm{cm})$ & Plant fresh weight (g) & Leaves number & Leaves weight (g) & Plant dry weight (g) & Leaves dry weight (g) \\
\hline & 20 DAT & & & & & \\
\hline $2 \mathrm{mM} \mathrm{SA}$ & $122 \pm 4^{a}$ & $68.0 \pm 2.7^{a}$ & $9 \pm 1^{a}$ & $35.0 \pm 1.2^{a}$ & $7.6 \pm 1.0^{\mathrm{a}}$ & $5.5 \pm 0.3^{a}$ \\
\hline $1 \mathrm{mM} \mathrm{SA}$ & $121 \pm 5^{a}$ & $57.7 \pm 2.3^{\mathrm{ab}}$ & $10 \pm 1^{\mathrm{a}}$ & $29.0 \pm 1.3^{\mathrm{ab}}$ & $6.6 \pm 0.4^{\mathrm{ab}}$ & $4.5 \pm 0.2^{\mathrm{ab}}$ \\
\hline $0.5 \mathrm{mM} \mathrm{SA}$ & $123 \pm 5^{a}$ & $63.3 \pm 1.8^{\mathrm{ab}}$ & $9 \pm 1^{a}$ & $32.3 \pm 2.1^{\mathrm{ab}}$ & $6.6 \pm 0.4^{\mathrm{ab}}$ & $4.6 \pm 0.2^{\mathrm{ab}}$ \\
\hline $0.25 \mathrm{mM} \mathrm{SA}$ & $121 \pm 6^{a}$ & $51.0 \pm 1.7^{b}$ & $9 \pm 1^{a}$ & $27.7 \pm 1.7^{b}$ & $4.8 \pm 0.3^{b}$ & $3.8 \pm 0.1^{\mathrm{ab}}$ \\
\hline \multirow[t]{2}{*}{ Control } & $119 \pm 5^{a}$ & $53.0 \pm 1.4^{b}$ & $9 \pm 1^{a}$ & $26.7 \pm 1.8^{\mathrm{b}}$ & $5.1 \pm 0.3^{b}$ & $3.5 \pm 0.2^{b}$ \\
\hline & 40 DAT & & & & & \\
\hline $2 \mathrm{mM} \mathrm{SA}$ & $175 \pm 7^{a}$ & $260 \pm 7^{a}$ & $14 \pm 1^{\mathrm{a}}$ & $103 \pm 3^{a}$ & $34.2 \pm 0.2^{a}$ & $18.5 \pm 0.4^{a}$ \\
\hline $1 \mathrm{mM} \mathrm{SA}$ & $176 \pm 6^{a}$ & $260 \pm 9^{a}$ & $14 \pm 1^{\mathrm{a}}$ & $102 \pm 4^{a}$ & $34.2 \pm 0.1^{a}$ & $18.4 \pm 0.3^{\mathrm{a}}$ \\
\hline $0.5 \mathrm{mM} \mathrm{SA}$ & $183 \pm 8^{a}$ & $257 \pm 7^{\mathrm{a}}$ & $14 \pm 1^{\mathrm{a}}$ & $102 \pm 4^{a}$ & $33.9 \pm 0.2^{a}$ & $18.4 \pm 0.2^{a}$ \\
\hline $0.25 \mathrm{mM} \mathrm{SA}$ & $190 \pm 8^{\mathrm{a}}$ & $278 \pm 8^{a}$ & $14 \pm 1^{\mathrm{a}}$ & $110 \pm 4^{\mathrm{a}}$ & $36.6 \pm 0.2^{a}$ & $19.8 \pm 0.4^{\mathrm{a}}$ \\
\hline Control & $171 \pm 6^{a}$ & $263 \pm 6^{a}$ & $14 \pm 1^{\mathrm{a}}$ & $104 \pm 5^{a}$ & $34.0 \pm 0.3^{a}$ & $18.8 \pm 0.3^{a}$ \\
\hline
\end{tabular}

Data within a column followed with the same letter are not significantly different at the level $5 \%$

enhancing effect of $0.25 \mathrm{mM}$ SA concentration on the germination percentage of the broad bean was reported by Anaya et al. (2018). Regarding the inhibition effect of IAA, Ramaih et al. (2003), Shuai et al. (2017), and Emem et al. (2017) showed that the exogenous application of the IAA delayed seeds germination of wheat, soybean, and Cucumis melo, respectively. Recently, Shuai et al. (2017) suggested that IAA can inhibit the germination process of soybean seeds through enhancing the abscisic-biosynthesis pathway and negatively mediated gibberellic-biosynthesis.

In this study, all SA and IAA treatments suppressed seedling growth of maize, when compared with the control seedlings. Moreover, a gradual decrease in seedling growth of 5-day-old seedlings was obtained by increasing the dose of SA or decreasing the dose of IAA. The most reducing effect was detected by using a higher concentration of SA (2 mM) and lower concentration of IAA $(0.25 \mathrm{mM})$. These results are in general agreement with those obtained by Chandra et al. (2007); they found that both germination and seedling growth of four cowpea genotypes were negatively affected by $0.02 \%(1.45 \mathrm{mM})$ SA application. On the contrary, many investigators recorded an enhancement effect on seedling growth due to pretreatment seeds with IAA (Zhao and Zhong 2013) or with SA (Anaya et al. 2018). These contradictory results might be attributed to the variability in species or in applied concentration or in soaking time. Moreover, we found that the inhibitory effect of tested hormones on the root growth of seedlings was apparently greater

Table 5 Effect of IAA foliar spray on vegetative growth of maize plants

\begin{tabular}{|c|c|c|c|c|c|c|}
\hline $\begin{array}{l}\text { Criteria } \\
\text { Treatments }\end{array}$ & Plant height (cm) & Plant fresh weight (g) & No of leaves & Leaves weight (g) & Plant dry weight (g) & Leaves dry weight (g) \\
\hline & 20 DAT & & & & & \\
\hline $2 \mathrm{mM} I \mathrm{AA}$ & $122 \pm 6^{\mathrm{a}}$ & $74.0 \pm 4.0^{\mathrm{ab}}$ & $9 \pm 1^{a}$ & $37.7 \pm 1.3^{\mathrm{ab}}$ & $7.5 \pm 0.3^{\mathrm{a}}$ & $5.2 \pm 0.2^{\mathrm{a}}$ \\
\hline $1 \mathrm{mM}$ IAA & $127 \pm 4^{a}$ & $66.0 \pm 3.0^{b}$ & $10 \pm 1^{\mathrm{a}}$ & $33.0 \pm 1.0^{\mathrm{b}}$ & $7.1 \pm 0.4^{\mathrm{a}}$ & 4. $9 \pm 0.3^{\mathrm{a}}$ \\
\hline $0.5 \mathrm{mM}$ IAA & $129 \pm 7^{\mathrm{a}}$ & $84.3 \pm 6.0^{\mathrm{a}}$ & $9 \pm 1^{a}$ & $40.3 \pm 1.7^{\mathrm{a}}$ & $8.0 \pm 0.6^{\mathrm{a}}$ & $5.4 \pm 0.3^{a}$ \\
\hline $0.25 \mathrm{mM}$ IAA & $129 \pm 6^{\mathrm{a}}$ & $74.0 \pm 4.0^{\mathrm{ab}}$ & $9 \pm 1^{a}$ & $36.3 \pm 2.0^{\mathrm{ab}}$ & $7.1 \pm 0.4^{\mathrm{a}}$ & $5.2 \pm 0.4^{\mathrm{a}}$ \\
\hline \multirow[t]{2}{*}{ Control } & $119 \pm 5^{a}$ & $53.0 \pm 3.0^{c}$ & $9 \pm 1^{\mathrm{a}}$ & $26.7 \pm 1.1^{c}$ & $5.1 \pm 0.3^{b}$ & $3.5 \pm 0.2^{b}$ \\
\hline & 40 DAT & & & & & \\
\hline $2 \mathrm{mM} I \mathrm{AA}$ & $195 \pm 8^{\mathrm{a}}$ & $330 \pm 9^{a}$ & $14 \pm 1^{\mathrm{a}}$ & $127 \pm 9^{a}$ & $43.2 \pm 3.1^{\mathrm{a}}$ & $22.9 \pm 0.9^{\mathrm{a}}$ \\
\hline $1 \mathrm{mM}$ IAA & $181 \pm 7^{\mathrm{ab}}$ & $260 \pm 7^{b}$ & $14 \pm 1^{\mathrm{a}}$ & $103 \pm 5^{b}$ & $34.2 \pm 2.9^{b}$ & $18.5 \pm 1.0^{\mathrm{b}}$ \\
\hline $0.5 \mathrm{mM}$ IAA & $183 \pm 6^{a b}$ & $259 \pm 7^{b}$ & $14 \pm 2^{\mathrm{a}}$ & $102 \pm 7^{b}$ & $34.1 \pm 1.7^{b}$ & $18.4 \pm 0.7^{b}$ \\
\hline $0.25 \mathrm{mM}$ IAA & $184 \pm 6^{\mathrm{ab}}$ & $259 \pm 8^{b}$ & $14 \pm 1^{\mathrm{a}}$ & $101 \pm 3^{b}$ & $34.0 \pm 1.9^{b}$ & $18.2 \pm 1.1^{b}$ \\
\hline Control & $169 \pm 5^{b}$ & $263 \pm 8^{b}$ & $14 \pm 1^{\mathrm{a}}$ & $105 \pm 4^{b}$ & $34.7 \pm 2.0^{b}$ & $18.8 \pm 0.8^{b}$ \\
\hline
\end{tabular}

Data within a column followed with the same letter are not significantly different at the level $5 \%$ 
than that on germination percentage or shoot growth. This result is indirectly in accordance with those reported by El-Mergawi and Al-Humaid $(2017,2019)$ and El-Mergawi and El-Desoki (2018). These studies showed that root growth was the most sensitive to allelopathic compounds than shoot growth and germination percentage.

The change in endogenous SA and IAA concentrations throughout eight DAT is in response to the exogenous application of two hormones in leaves of greenhouse-grown maize. The results indicated that the endogenous active forms of SA and IAA were responded positively to all their exogenous application treatments peaking at 2 DAT and subsequently decreasing gradually. Different plant species responded in a distinct manner to varying amounts of exogenous SA GuzmánTéllez et al. 2014 or IAA (Korasick et al. 2013; Al-Amri 2018; Cai et al. 2018) treatments. However, plants treated with SA at 1 and $2 \mathrm{mM}$ only continued to possess higher levels of endogenous SA than those of control over the entire time of the measuring period, whereas, at $8 \mathrm{DAT}$, the IAA content in the all IAAtreated leaves was not possessed any significant difference as compared with the corresponded control. The rapid decrease in the endogenous SA and IAA, after the peak concentration, seems to be partially due to the transformation of two hormones into its conjugated forms (He et al. 2007; Ludwig-Muller 2011).

The results indicated that spraying SA or IAA at $0.25-$ $2 \mathrm{mM}$ produced significant increases in growth traits of maize plants when measured 20 DAT. The enhancing effect of SA and IAA on plant growth was reported by many investigators Guzmán-Téllez et al. 2014; Khandaker et al. 2018). Although, at 40 DAT, except the increment effect of $2 \mathrm{mM}$ IAA on maize growth, all SA and IAA treatments did not produce any significant effect on tested growth parameters when compared with those of control. In this concern, Guzmán-Téllez et al. (2014) found some differences in the values of stem and leaves of tomato between SA treated plants $(0.1 \mathrm{mM})$ and control plants at 4, 12, and 15 DAT and disappeared at the end of the assay (22 DAT). The disappearance of the enhancing effect of SA and IAA treatments in growth parameters over time may be related with the decrease in the levels of endogenous SA or IAA in treated plants by time as previously mentioned. It is assumed that the endogenous SA or IAA concentrations must be kept at an appropriate level to maintain an enhancement effect on growth parameters (Guzmán-Téllez et al. 2014).

\section{Conclusions}

In this study, the effect of pre-soaking maize seeds in SA and IAA on germination, uptake, and distribution of endogenous two hormones in soaked seeds and 5-day-old seedlings was determined. A higher ability of maize seeds on uptake SA was detected accompanied with a relatively lower ability of seeds on uptake IAA. The two hormones were found in different seedling tissues, and its contents were positively correlated with the exogenously applied concentrations. In young seedlings, the majority of two hormones which absorbed during seed soaking localized in the residual seeds. Pre-soaking seeds in SA and IAA solutions suppressed seedling growth of maize. In the greenhouse experiment, endogenous SA and IAA were increased after foliar spray of two compounds at $0.25-2 \mathrm{mM}$, peaking 2 days after treatment and then decreased on. However, plants treated with SA at $1 \mathrm{mM}$ or $2 \mathrm{mM}$ continued to possess higher levels of endogenous SA, 8 days later. All SA and IAA treatments significantly increased the fresh and dry weights of leaves and plants, when measured after 20 days, whereas by extending the period of measuring to 40 days, most of these inducing effects disappeared. Generally, the obtained results increased our knowledge about the changes induced in endogenous SA and IAA in soaked seeds, seedling tissues, and foliar-sprayed plants due to their exogenous application and their relations with germination and growth in maize.

\section{Abbreviations}

SA: Salicylic acid; IAA: Indole acetic acid; mM: Mille molar; $\mu \mathrm{M}$ : Micromolar; RP: Reversed phase; DAT: Days after treatment; g: Gram; GA: Gibberellic acid; LSD: Least significant difference; $\mathrm{pH}$ : The negative logarithm of the hydrogen ion concentration

\section{Acknowledgements}

Not applicable.

\section{Authors' contributions}

All authors conceived and designed the experiments, read, and approved the final manuscript. MSAA performed the experiment and analyzed the data. RAE contributed to reagents/materials/analysis tools and wrote the paper. The authors have read and approved the final manuscript.

\section{Funding}

National Research Centre, Egypt.

Availability of data and materials

The datasets generated and/or analyzed during the current study are included in this published study.

Ethics approval and consent to participate Not applicable.

Consent for publication

Not applicable.

\section{Competing interests}

The authors declare that they have no conflict of interest.

Received: 29 April 2020 Accepted: 1 September 2020

Published online: 23 September 2020

\section{References}

Al-Amri SM (2018) Functional activity of some growth regulators on yield components and endogenous hormones of cowpea plants (Vigna sinensis L.). Agric. Sci. 9:1229-1239 
Anaya F, Fghire R, Wahbi S, Loutfi K (2018) Influence of salicylic acid on seed germination of Vicia faba L. under salt stress. J. Saudi Soc. Agric. Sci 17:1-8

Cai T, Meng X, Liu X, Liu T, Wang H, Jia Z, Yang D, Ren X (2018) Exogenous hormonal application regulates the occurrence of wheat tillers by changing endogenous hormones. Front. Plant Sci 9:Article 1886

Canakci S, Munzuroglu O (2007) Effects of acetylsalicylic acid on germination, growth and chlorophyll amounts of cucumber (Cucumis sativus L.) seeds. Pakistan J. Biol. Sci 10(17):29330-22934

Chandra A, Anand A, Dubey A (2007) Effect of salicylic acid on morphological and biochemical attributes in cowpea. J. Environ. Biol. 28:193-196

Chauhan JS, Tomar YK, Singh NI, Debarati SA (2009) Effect of growth hormones on seed germination and seedling growth of black gram and horse gram. J. American Sci. 5:79-84

El-Mergawi RA (2019) Suitability of high doses of phenolic acids for controlling Corchorus olitorius and Phalaris minor weeds. Gesunde Pflanzen 71(4):261-269

El-Mergawi RA, Al-Humaid A (2017) Evaluation the allelopathic potential of fractions obtained from some native plants on Portulaca oleracea and Echinochloa crusgalli weeds. Bull NRC 41:273-285

El-Mergawi RA, Al-Humaid A (2019) Searching for natural herbicides in methanol extracts of eight plant species. Bull NRC 43:22-28

El-Mergawi RA, El-Desoki E (2018) Allelopathic activities of celery extract and its fractions against Corchorus olitorius, Echinochloa crusgalli and Portulaca oleracea weeds. Adv. Hort. Sci. 32:503-510

Emem O, Akeem AA, Fawibe O, Tolulope A, Oluwasey A, David A (2017) Effects of phytohormone on seed germination, seedling vigour and the phytochemical contents of three cucurbits. Asian J. Crop Sci. 9:63-70

Gomez KA, Gomez AA (1984) Statistical procedures for agricultural research. John Wiley \& Sons Inc., Singapor

Guan L, Scandalios JG (1995) Developmentally related responses of maize catalase genes to salicylic acid. Proc. Natl. Acad. Sci. USA 92:5930-5934

Guzmán-Téllez E, Montenegro DD, Benavides-Mendoza A (2014) Concentration of salicylic acid in tomato leaves after foliar aspersions of this compound. Am J. Plant Sci. 5:2048-2056

He W, Li H, Li X, Li MQ, Chen YW (2007) Tetranynchus urticae Koch induced accumulation of salicylic acid in frijole leaves. Pest. Bioch. Physiol. 88:78-81

Khandaker MM, Azam HM, Rosnah J, Tahir D, Nashriyah M (2018) Effects of application of exogenous IAA and $\mathrm{GA}_{3}$ on the physiological activities and quality of Abelmoschus esculentus (Okra) var. Singa 979. J. Tropical Agric. Sci 41:209-224

Kim SK, Son TK, Park SY, Lee IJ, Lee BH, Kim HY, Lee SC (2006) Influences of gibberellin and auxin on endogenous plant hormone and starch mobilization during rice seed germination under salt stress. J. Environ. Biol. 27:181-186

Korasick DA, Enders TA, Strader LC (2013) Auxin biosynthesis and storage form. J. Exp. Botany 64:2541-2555

Ludwig-Muller J (2011) Auxin conjugates: their role for plant development and in the evolution of land plants. J. Exp. Botany 62:1757-1773

Marambe B, Ando T (1992) Phenolic acids as potential seed germinationinhibitors in animal-waste composts. Soil Sci. Plant Nut. 38:727-733

Matallo MB, Almeida SDB, Franco DAS, Cerdeira AL, Gazzeiro DLP (2009) Glyphosate as a tool to produce shikimic acid in plants. Planta Daninha 32: 601-608

Moravcová S, Tůma J, Dučaiová ZK, Waligórski P, Kula MA, Saja D, Słomka A, Bąba W, Libik-Konieczny M (2018) Influence of salicylic acid pretreatment on seeds germination and some defence mechanisms of Zea mays plants under copper stress. Plant Physiol. Bioch. 122:19-30

Muscolo A, Panuccio MR, Sidari M (2001) The effect of phenols on respiratory enzymes in seed germination. Plant Growth Regul. 35:31-35

Negi S, Prasad SP (2001) Effect of salicylic acid on enzymes of nitrogen metabolism during germination of soybean. Indian J. Plant Physiol. 2:178-181

Pérez-Llorca M, Muñoz P, Müller M, Munné-Bosch S (2019) Biosynthesis, metabolism and function of auxin, salicylic acid and melatonin in climacteric and non-climacteric fruits. Front. Plant Sci 10:Article 136

Rajjou L, Belghazi M, Huguet R, Robin C, Moreau A, Job C, Job D (2006) Proteomic investigation of the effect of salicylic acid on Arabidopsis seed germination and establishment of early defense mechanisms. Plant Physiol. 141:910-923

Ramaih S, Guedira M, Paulsen GM (2003) Relationship of indole acetic acid and tryptophan to dormancy and preharvest sprouting of wheat. Funct. Plant Biol. 30:939-945
Shuai H, Meng Y, Luo X, Chen F, Zhou W, Dai Y, Qi Y, Du J, Yang, Liu J, Yang W, Shu K (2017) Exogenous auxin represses soybean seed germination through decreasing the gibberellin/abscisic acid (GA/ABA) ratio. Sci. Rep 7:Article number 12620

Szalai G, Horgosi S, Soos V, Majlath I, Balazs E, Janda T (2011) Salicylic acid treatment of pea seeds induces its de novo synthesis. J. Plant Physiol. 168: 213-219

Vicente MR, Plasencia J (2011) Salicylic acid beyond defence: its role in plant growth and development. J. Exp. Bot. 62:3321-3338

Wani AB, Chadar H, Wani AH, Singh S, Upadhyay N (2017) Salicylic acid to decrease plant stress. Enviorn. Chem. Lett. 15:101-123

Xiao Z, Chunqin Z, Jing H, Deng'an X, Chihong Z, Jing C (2014) Effect of exogenous abscisic acid and salicylic acid on germination and physiological characteristics of wheat seed. Chinese J. Appl. Environ. Biol. 20:139-143

Zhao G, Zhong GT (2013) Influence of exogenous IAA and GA on seed germination, vigor and their endogenous levels in Cunninghamia lanceolata. Scandinavian J. Forest Res. 28:511-517

Zhao YD (2010) Auxin biosynthesis and its role in plant development. Annu. Rev. Plant Biol. 61:49-64

Zhou Y, Tong Y, Jiao Z, Yi-tao NW, Qi W, Fei S, Wen-Juan XU, Rui-dong H (2017) Effects of exogenous IAA application on endogenous hormone contents and tillering in sorghum. Chinese J. Ecol. 36:2191-2197

\section{Publisher's Note}

Springer Nature remains neutral with regard to jurisdictional claims in published maps and institutional affiliations.

\section{Submit your manuscript to a SpringerOpen ${ }^{\circ}$ journal and benefit from:}

- Convenient online submission

- Rigorous peer review

- Open access: articles freely available online

- High visibility within the field

- Retaining the copyright to your article

Submit your next manuscript at $>$ springeropen.com 